\title{
Environmental, genetic and viral risk factors of nasopharyngeal carcinoma in North Africa
}

\author{
Nadia Laantri ${ }^{1 *}$, Marilys Corbex ${ }^{2}$, R'kia Dardari $^{3}$, Abdellatif Benider $^{4}$, Brahim El Gueddari ${ }^{5}$, Meriem Khyatti ${ }^{1}$ \\ From Institut Pasteur International Network Annual Scientific Meeting \\ Hong Kong. 22-23 November 2010
}

NPC (Nasopharyngeal carcinoma) is a tumour that arises in the epithelium surface of the posterior nasopharynx and shows a peculiar geographic and ethnic distribution. Intermediate incidence (8-12 cases/100,000/ year) was reported in the North African population (7$10 \%$ of all cancers among men), where NPC is also the commonest tumour of the ear, nose and throat region.

In Asia, the majority of the cases occur in the fifth and sixth decades of life. In contrast, in North Africa the age distribution is bimodal with a minor peak in people aged between 10 and 25 years old. This juvenile form accounts for approximately $20 \%$ of the patients and has specific clinical and biological features. Geographical correlation was also observed between percentages of young cases and consanguinity rates over endemic and non-endemic populations, which may therefore explain the shape of the age curve in North Africa.

Regardless of its incidence and geographic distribution, NPC results from the contribution of environmental, genetic and viral factors. These factors might however combine differently for Asian and North African patients and also among North African patients of the two age groups.

\section{Environmental factors}

The increased risk of NPC was associated with the consumption of rancid butter and rancid sheep fat. Butyric acid contained in these products is considered as a potential Epstein-Barr virus (EBV) activator and a possible causative substance for NPC. In addition, Marijuana smoking was associated significantly to high NPC risk independently of cigarette smoking which suggests dissimilar carcinogenic mechanisms between cannabis and tobacco.

\section{Genetic factors}

Genetic traits play a significant role in the development of NPC. Specific human leukocyte antigen (HLA) haplotypes have been reported to be associated with high risk for NPC, namely HLA-B13 in Tunisians, HLA-A3, B5 and B15 in Algerians and HLA-B18 allele in Moroccans population. In contrast, HLA-Aw33, -B14 and A9 were associated to low risk of NPC in Tunisians, Algerians and Moroccans, respectively.

\section{Viral factors}

EBV is etiologically associated with NPC, and the distribution of Latent Membrane Protein (LMP)-1 variants of EBV in NPC tumors co-segregate with geographic regions. Moroccan NPC patients showed a high prevalence of the 30bp deletion variant of LMP-1; the delLMP-1 variant share identical amino acid substitutions with the Med variant. Evidence indicates that NPCderived LMP-1 variants carrying 30bp deletion and specific mutations in the $3 \mathrm{C}$-terminal region confer high oncogenic potential and a weak immunogenicity.

However, although it is widely accepted that EBV is etiologically associated with NPC; it is proven that other co-factors might be involved in the carcinogenesis process, such as HPV (Human papilloma virus) factors. Our results report that $34 \%$ of EBV positive Moroccan NPC biopsies harbour HPVs.

\footnotetext{
Author details

${ }^{1}$ Institut Pasteur du Maroc, Casablanca, Morocco. ${ }^{2}$ WHO Regional Office for the Eastern Mediterranean Region, Cairo, Egypt. ${ }^{3}$ Saint Justine Hospital,
}

${ }^{1}$ Institut Pasteur du Maroc, Casablanca, Morocco

Full list of author information is available at the end of the article

(C) 2011 Laantri et al; licensee BioMed Central Ltd. This is an open access article distributed under the terms of the Creative Commons 
Montreal, Canada. ${ }^{4}$ Oncology Center, CHU Averroes, Casablanca, Morocco.

${ }^{5}$ National Institute of Oncology, CHU Avicenne Rabat, Morocco.

Published: 10 January 2011

doi:10.1186/1753-6561-5-S1-P30

Cite this article as: Laantri et al.: Environmental, genetic and viral risk

factors of nasopharyngeal carcinoma in North Africa. BMC Proceedings

2011 5(Suppl 1):P30.

Submit your next manuscript to BioMed Central and take full advantage of:

- Convenient online submission

- Thorough peer review

- No space constraints or color figure charges

- Immediate publication on acceptance

- Inclusion in PubMed, CAS, Scopus and Google Scholar

- Research which is freely available for redistribution

Submit your manuscript at 